\title{
Korzystanie z Internetu jako źródło zagrożeń zdrowia i rozwoju dzieci i młodzieży
}

\author{
DOROTA KACHLICKA
}

SWPS Uniwersytet Humanistycznospołeczny, ul. gen. Tadeusza Kutrzeby 10, 61-719 Poznań ORCID 0000-0001-9695-0235,E-mail:dusia9619@gmail.com

STRESZCZENIE: Cyberprzemoc to rodzaj agresji zagrażający zdrowiu i rozwojowi dzieci oraz młodzieży. Konsekwencją jej doświadczania są zaburzenia zachowania, lęk, objawy somatyczne, a także samobójstwa wśród nastolatków. W pierwszej części artykułu zdefiniowane zostało zjawisko cyberprzemocy, jej formy i drogi rozpowszechniania. Przedstawiono zaburzenia zagrażające zdrowiu i rozwojowi młodzieży oraz badania z zakresu cyberprzemocy. Część druga stanowi prezentację założeń teoretycznych, które wyjaśniają szkodliwość oddziaływania cyberprzemocy na rozwój nastolatków, zaś trzecia jest propozycją szkolnego programu profilaktycznego chroniącego młodych użytkowników sieci.

SŁOWA KLUCZOWE: cyberprzemoc, zdrowie, dzieci, nastolatek

\section{WSTĘP}

Nadużywanie internetu przez młodzież oraz związek $\mathrm{z}$ występowaniem $\mathrm{w}$ tej grupie przypadków cyberprzemocy okazuje się współcześnie ważnym problemem. Dynamiczny rozwój nowych technologii, powszechniejszy dostęp do internetu i różnorakich środków przekazu, a także potrzeba bycia w stałym kontakcie niemalże z całym światem często staje się zalążkiem wielu analiz w dziedzinie psychologii rozwoju dzieci i młodzieży. Coraz to młodsze pokolenia sięgają po tablet, komputer czy telefon $z$ dostępem do internetu i gier komputerowych, co zwiększa ilość przypadków cyberprzemocy. Zjawisko to definiowane jest przez niektórych jako powtarzające się celowe działania prowadzące do wywołania krzywdy u ofiary (Albański 2010). Ma ono różnorodne formy oraz drogi rozpowszechniania. To, co dzieje się w świecie „wirtualnym”, ma swój oddźwięk w świecie „realnym” i znacząco wpływa na funkcjonowanie dzieci i nastolatków w świecie w ogóle. Mimo to wiedza na temat możliwych zagrożeń i szkodliwości sieci zarówno w grupie nastolatków jak i rodziców wciąż jest niewystarczająca. Biorąc pod uwagę różnorodność zagrożeń związanych z korzystaniem $\mathrm{z}$ internetu przez młodzież, celem artykułu będzie w pierwszej kolejności dokładna analiza podjętego zagadnienia, następnie przeanalizowanie konsekwencji i wpływu zjawiska na zdrowie 
oraz rozwój dzieci i młodzieży. Ostatnim elementem pracy jest prezentacja propozycji programu prewencyjnego wprowadzonego w szkołach w celu edukacji i ochrony młodzieży przed niebezpieczeństwami sieci.

W części pierwszej omówiono zagadnienia związane $\mathrm{z}$ problemem cyberprzemocy wśród młodzieży, to jest: przedstawiono dokładną definicję, drogi rozpowszechniania i formy internetowej agresji; odróżniono cyberprzemoc od przemocy $\mathrm{w}$ tradycyjnym jej ujęciu; przedstawiono sylwetki sprawcy i ofiary; scharakteryzowano konsekwencje zjawiska zakłócające prawidłowe funkcjonowanie nastolatka, takie jak: zaburzenia zachowania, lęk i objawy somatyczne, a także samobójstwa; w końcu przeanalizowano zebrane badania oraz analizy naukowe dotyczące cyberprzemocy.

W drugiej części opisano: zagadnienia teoretyczne związane z pojęciem cyberprzemocy; wyjaśniono zjawisko w oparciu o model podatności na stres; teorie rozwojowe oparte o zadania rozwojowe Havighursta (1981); teorie rozwoju psychospołecznego Eriksona, a także teorie frustracji agresji; wytłumaczono wpływ cyberprzemocy będącej czynnikiem stresującym, zakłócającym prawidłowe funkcjonowanie nastolatka; przedstawiono także jej związek z realizacją zadań rozwojowych oraz rozwiązywanie kryzysów w wieku szkolnym i okresie dorastania; wykazano współzależność ze wzrostem zachowań agresywnych wśród ofiar i sprawców zjawiska.

W trzeciej części zaproponowano szkolny program profilaktyki dotyczący zjawiska cyberprzemocy. Działaniami w ramach programu mają zostać objęci uczniowie w młodszym wieku szkolnym oraz młodzież będąca w okresie dorastania Głównym celem programu jest ochrona i edukacja współczesnej młodzieży w zakresie zapobiegania cyberprzemocy, a także bezpiecznego korzystania z sieci.

\section{KORZYSTANIE Z INTERNETU I CYBERPRZEMOC}

Internet umożliwia komunikację niemalże z całym światem, daje użytkownikom możliwość czerpania wiedzy z każdej dziedziny. To sprawia, że świat wirtualny staje się dla młodego człowieka atrakcyjniejszy od świata realnego. To, co dzieje się w wirtualnej przestrzeni w znacznym stopniu determinuje życie młodzieży, a korzystanie z internetu stanowi jego nieodzowną część. Współcześnie młodzi ludzie już od najmłodszych lat mają styczność z siecią, mogą bowiem połączyć się ze światem wirtualnym w bardzo prosty sposób - nawet poprzez telefon czy telewizor. Świat wirtualny może z jednej strony oferować nowe możliwości, a z drugiej stać się źródłem wielu niebezpieczeństw (Guerreschi 2006).

Nowemedia stwarzają szereg możliwości dydaktycznych, dlatego korzystanie zdobrodziejstw sieci jest coraz bardziej powszechne w szkołach. Należy jednak mieć świadomość, że internet to przestrzeń, z którą związane może być także wiele zagrożeń. Anonimowość użytkowników sieci daje okazję do wyrażania siebie - bez kontroli, ograniczeń czy nadzoru. Internet stał się doskonałym nośnikiem do przekazywania informacji zarówno pozytywnych, jak i tych mających negatywny wydźwięk (Guerreschi 2006). Brak nadzoru, ochrony oraz perspektywa anonimowości daje młodym ludziom poczucie bezkarności względem ich poczynań w 
świecie wirtualnym. To z kolei prowadzi do niewłaściwego sposobu korzystania z internetu przez młodych użytkowników, a także coraz powszechniejszych wśród nich przypadków cyberprzemocy.

\subsection{DEFINIOWANIE CYBERPRZEMOCY}

W literaturze przedmiotowej kluczową kwestią braną pod uwagę przy definiowaniu zjawiska cyberprzemocy jest narzędzie realizacji działań agresywnych. Jest ona w związku $\mathrm{z}$ tym definiowana jako przemoc tradycyjna, $\mathrm{z}$ tą jednak różnicą, że w przypadku jej realizacji wykorzystywane są nowe technologie (Pyżalski 2012). To powtarzające się umyślne działania sprawców, które często mają charakter anonimowy i mogą przybierać różne formy, a do ich realizacji wykorzystywany jest internet (Albański 2010). Akty agresji realizowane za pomocą nowych mediów, takich jak e-maile, telefony komórkowe, zdjęcia czy filmy przesyłane za pośrednictwem internetu często w literaturze nazywane są także agresją elektroniczną. Ma ona zarówno pośredni jak i bezpośredni charakter. Bezpośrednie ataki określa się jako kierowanie w internecie działań agresywnych bezpośrednio w stronę innych osób. Natomiast w przypadku agresji pośredniej mówimy o sytuacji, w której wykorzystuje się postronne osoby do stosowania agresji wobec wybranej ofiary. Ważnym aspektem owej formy cyberprzemocy jest obustronna świadomość i zgoda na ten rodzaj współpracy.

W celu zobrazowania skali i zasięgu zjawiska cyberprzemocy Centrum Badania Opinii Społecznej przeprowadziło badania wśród młodzieży z różnych środowisk szkolnych (2016). W edycji badań „Młodzież” rozszerzono spektrum pytań o zagadnienia związane z cyberprzemocą. Wyniki okazały się stosunkowo różnorodne, bowiem zależne w dużej mierze od typu szkoły, do jakiej uczęszczały osoby badane. Uczniowie zasadniczych szkół zawodowych częściej doświadczali przemocy niż uczniowie innych szkół. Natomiast dwie formy doświadczania agresji przeanalizowane w badaniu okazały się dotykać uczniów równie często, niezależnie od typu szkoły. Są to publikowanie w internecie informacje i zdjęcia, których badany nie chciał ujawniać oraz wykluczenie. Porównanie wyników z różnych typów szkół wskazuje, że chłopcy, częściej niż dziewczęta, doświadczają różnych form przemocy. W zasadniczych szkołach zawodowych sytuacja jest wyjątkowo zła $-42 \%$ spośród respondentów odpowiada, że częstym zjawiskiem jest przemoc wobec chłopaków, natomiast $31 \%$ wskazuje na wystąpienie przypadków przemocy wobec dziewcząt. Wyniki badań CBOS(2016) w sferze cyberprzemocy wykazały także, że młodzi ludzie doświadczali różnych jej form ze strony innych. 8\% ankietowanych otrzymywało wiadomości o obraźliwej treści od kolegi/ koleżanki. Także 8\% badanych wskazało na doświadczenie sytuacji, w której opublikowano w internecie informacje, której nie chcieli ujawnić. Cyberprzemoc łącznie dotknęła 13\% spośród przebadanych uczniów. Warto zwrócić uwagę na to, iż 3\% badanych spotkało się z obiema formami cyberprzemocy, zaś tylko $5 \% \mathrm{z}$ nich doświadczyło jednej z nich. Istotne z punktu widzenia analizy zjawiska cyberprzemocy mogą być także wyniki w zakresie cyberprzemocy stosowanej przez uczniów względem nauczycieli. Odpowiedzi badanych w tym aspekcie wskazują, że $28 \% \mathrm{z}$ nich potwierdza przypadki stosowania owego rodzaju przemocy względem nauczyciela w szkole, 
do której uczęszczają. Badania potwierdzają także przypadki zamieszczania obraźliwych i kompromitujących nauczycieli materiałów w sieci. Dodatkowo 17\% spośród ankietowanych potwierdza, że zdarzyło się to częściej niż raz.

Koncentrując uwagę na zjawisku cyberprzemocy zbadano także, kto może stać się sprawcą, a kto może paść ofiarą internetowej agresji. Badania (Mishna, Khoury-Kassabri, Gadalla, Daciuk 2012) wykazały, że starsi uczniowie częściej mogą stać się sprawcą zarówno jednorazowego zastosowania agresji w internecie, jak i długotrwałego nękania, a więc są częściej narażeni na styczność z cyberprzemocą. Uczniowie ci mogą także wykazywać się niższym poczuciem bezpieczeństwa. Dodatkowo badanie udowodniło, iż uczniowie częściej korzystający z komputera są jednocześnie częściej powiązani z działaniami o charakterze cyberprzemocowym.

\subsection{CYBERPRZEMOC A PRZEMOC TRADYCYJNA}

Różnica pomiędzy cyberprzemocą a przemocą $\mathrm{w}$ tradycyjnym jej ujęciu jest stosunkowo niewielka, jednakże różni się ona pod względem stosowanych narzędzi. Warto zatem zastanowić się nad tym, czy podstawowe dla tradycyjnej agresji przejawy i mechanizmy mają znaczenie także w przypadku agresji elektronicznej. W literaturze dokonuje się rozróżnienia w obrębie trzech właściwości, jakimi są: (1) powtarzalność, (2) nierównowaga sił i (3) intencjonalność stosowania różnorakich form agresji (Pyżalski 2012). Powtarzalność w tradycyjnym ujęciu agresji oznacza działanie wielokrotnie ponawiane przez sprawców. Natomiast w przypadku agresji elektronicznej wynika ona z cech materiału zamieszczonego w internecie. Nierównowaga sił to z kolei właściwość wynikająca z przewagi sprawców agresji. Przewaga przybiera różnorodne formy i wynika z faktu, iż internet stanowi olbrzymią, połączoną ze sobą sieć, dającą możliwość szybkiego rozprzestrzeniania się obraźliwych informacji. To sprawia, że oprawcy mają świadomość przewagi nad swoją ofiarą. W przypadku tradycyjnie rozumianej agresji oprawców charakteryzuje poczucie dominacji nad swoją ofiarą, czują się silniejsi zarówno fizycznie, jak i psychicznie. Z kolei cyberprzemoc jest wynikiem niedostatecznej kompetencji ofiar w zakresie stosowania nowych technologii. Nieświadomość i brak wiedzy w tym zakresie sprawia, że nastolatek łatwo może stać się ofiarą. Intencjonalność powiązana jest ze świadomością podejmowanego działania. Agresja tradycyjna jest więc świadomym, celowym działaniem sprawcy, którego celem jest skrzywdzenie swojej ofiary. Cyberprzemoc, jako forma agresji posiadająca często pośrednią formę, może być natomiast działaniem nieświadomym.

\subsection{DROGI ROZPOWSZECHNIANIA ZJAWISKA}

Zróżnicowanie technologii komunikacyjnych sprawia, że młody użytkownik sieci może doświadczyć cyberprzemocy na wiele sposobów. Służy ku temu wiele źródeł komunikacji współczesnej młodzieży, powiązane z takimi działaniami, jak wysyłanie obraźliwych wiadomości, zdjęć czy filmów przy pomocy komunikatorów internetowych. Przestrzenią do szerzenia się agresji wśród młodych ludzi jest niewątpliwie poczta elektroniczna. Pozwala ona łatwo i szybko przesyłać kompromitujące ofiarę informacje do wielu osób jednocześnie. Podobnie dzieje się w przypadku wiadomości tekstowych oraz portali społecznościowych, 
które stanowią element ich współczesnego świata, są rodzajem „okna” młodzieżowej kultury. Zapewniony przez obie te formy komunikacji pewien pozorny poziom anonimowości wpływa na to, że młodzi ludzie nie selekcjonują nadawanych komunikatów, często nie kontrolując swojego zachowania względem innych w świecie wirtualnym. Wykorzystywane przez młodzież czaty również stają się narzędziem szerzenia cyberprzemocy. Obecność na nich wielu użytkowników daje sposobność do oczerniania obcych sobie ludzi. Powszechną przestrzenią znaną nastolatkom są blogi i strony internetowe. One także stały się miejscem, w którym młodzież prezentować może zachowania agresywne. Należy również podkreślić, że wiele blogów czy stron internetowych powstaje specjalnie w celu niszczenia reputacji, zamieszczania prywatnych informacji i zdjęć innych osób, które stają się ofiarami cyberprzemocy (Kowalski, Limber, Agatston 2010). Ważne są także forma i sposób rozpowszechniania, gdy mowa o rozpoznawaniu potencjalnych ofiar i sprawców zjawiska. Zagadnienia te były przedmiotem obserwacji wielu badaczy problematyki cyberprzemocy. Na przykład w badaniach przeprowadzonych przez Pyżalskiego (2012) dokonano wieloaspektowej analizy problemu cyberprzemocy wśród gimnazjalistów. W trakcie analiz skoncentrowano się na rozpoznaniu przejawów zjawiska, uwarunkowań i konsekwencji jego występowania, skupiono uwagę zarówno na roli sprawcy, ofiary oraz sprawco-ofiar definiowanych jako osoby, które będąc sprawcami cyberprzemocy, mogą stać się także jej ofiarami. W badaniu wzięli udział uczniowie trzeciej klasy gimnazjum, z placówek na terenie ośmiu polskich województw (podlaskiego, lubelskiego, małopolskiego, śląskiego, dolnośląskiego, wielkopolskiego, pomorskiego, mazowieckiego). Najbardziej istotną częścią badań jest analiza wyników z zakresu poziomu sprawstwa i witalizacji agresji elektronicznej przy pomocy czatu i komunikatorów internetowych. Badania wykazały, że 56\% badanych nigdy nie było sprawcami agresji elektronicznej (Pyżalski 2012). Nieco inaczej wyniki prezentują się w przypadku forum internetowego, będącego stosunkowo łatwą przestrzenią do manifestowania agresji względem innych. Ponad 36,5\% respondentów przyznaje, że skorzystało z tego kanału w celu manifestowania agresji podczas uczestnictwa w grach. Dodatkowo wykazano, iż 29\% przebadanych osób przyznaje, że skorzystało z tej formy w ciągu roku poprzedzającego badanie. Analizy wyników w zakresie wykluczenia wykazały, iż 31\% spośród przebadanych osób dopuściło się takiej agresji względem innych. Gimnazjaliści przyznali także, że zdarzyło im się wysłać obraźliwe SMS-y oraz komentować czyjeś profile w celu obrażenia bądź sprawienia przykrości.

W przypadku problematyki wiktymologii koncentrowano się na przeanalizowaniu negatywnych doświadczeń, odczuć ofiar i ich związku ze stosowanym rodzajem cyberprzemocy. Respondenci przyznają, iż otrzymywali nieprzyjemne SMS-y, w tym 35\% z nich kiedykolwiek, $18 \%$ w ciągu roku poprzedzającego przeprowadzenie badania. Ofiarami wyzwisk podczas rozmów na czacie było $31,6 \%$ spośród badanych, 18\% z nich doświadczyło tego w przeciągu roku poprzedzającego badanie. Spory odsetek spośród badanych doświadczył także okłamywania za pośrednictwem internetu, a także nieprzyjemnych komentarzy umieszczanych na ich kontach społecznościowych. Rozważania uwidaczniają tylko niektóre z przeanalizowanych w badaniu form wiktymizacji i sprawstwa cyberprzemocy. Należy pamiętać o tym, że spektrum 
agresywnych działań w sieci jest duże i bardzo różnorodne. Każda ze stosowanej formy agresji elektronicznej może w znaczący sposób wpływać na psychikę i prawidłowy rozwój młodego użytkownika sieci.

\subsection{FORMY CYBERPRZEMOCY}

Zagrożenie cyberprzemocą może dotknąć młodego użytkownika sieci w bardzo różny sposób, ze względu na różnorodne jego drogi rozpowszechniania. Równie ważna jest także forma stosowanej agresji elektronicznej. Istnieją różne formy cyberprzemocy: flamming, prześladowanie, oczernianie czy pozyskiwanie tajemnic za pośrednictwem internetu, cyberostracyzm oraz happy slapping (Kowalski, Limber, Agatston 2010).

Charakterystyczne działania, które można uznać za przejaw cyberprzemocy, to często stosowana wojna na obelgi (flamming). Zjawisko to charakteryzuje krótka, zaciekła wymiana zdań między użytkownikami sieci. Najczęściej nastolatkowie mogą zetknąć się z nim na wspomnianych wcześniej czatach czy forach internetowych.

Długotrwałe działanie skierowane w stronę konkretnej osoby, które ma doprowadzić do wywołania dyskomfortu emocjonalnego, stanu niepokoju u drugiej osoby, to prześladowanie. Cechą charakterystyczną, która odróżnia je spośród innych form, jest jasne rozróżnienie atakującego, poszkodowanego i celu danego postępowania. W przypadku innych form cyberprzemocy rozróżnienie to nie jest aż tak wyraźne, natomiast w przypadku prześladowania oczywistym jego celem jest odebranie innym użytkownikom przyjemności korzystania z internetu.

Przekazywanie fałszywych informacji o innej osobie to najistotniejszy element formy cyberprzemocy nazywanej oczernianiem. Ten rodzaj internetowej agresji obejmuje e-maile, zdjęcia przesyłane i publikowane w celu poniżenia innej osoby.

Pozyskiwanie tajemnic, prywatnych informacji od innych osób również traktowane jest jako jedna z form internetowej agresji. Może być źródłem niebezpieczeństwa dla nastolatków. Takie działanie może zostać uznane za cyberprzemoc, kiedy internetowy oprawca, otrzymując jakiekolwiek poufne informacje od swojego współrozmówcy, udostępnia je do wglądu innym użytkownikom sieci.

W przypadku grup charakterystyczną formą agresji jest cyberostracyzm. Wydaje się, że młoda, prawidłowo rozwijająca się i funkcjonująca jednostka, chce być członkiem określonej społeczności. Wykluczenie z grupy w sieci może w znaczącym stopniu wpływać na emocje dziecka, które korzysta $\mathrm{z}$ internetu.

Forma cyberprzemocy, w której sprawca notorycznie wykorzystuje wszelkie środki wirtualnej komunikacji do prześladowania drugiej osoby, to cybernękanie.

Z kolei happy slapping jest całkowicie nowym rodzajem cyberprzemocy. Zjawisko to polega na rejestrowaniu filmów z aktami przemocy. Nagrania tych zdarzeń zamieszczane są później w internecie, dopuszczone do wglądu innych użytkowników, dając im możliwość komentowania zarejestrowanego zdarzenia (Kowalski,Limber, Agatston 2010). 


\subsection{KONSEKWENCJE CYBERPRZEMOCY}

Charakterystyczne dla problemu cyberprzemocy są szybkość rozprzestrzeniania i powszechna dostępność obraźliwych materiałów. Osoby, wobec których stosowany jest ten rodzaj przemocy, czują się często bezbronne i nieszczęśliwe (Szeligiewicz-Urban 2016). Bezustannie odczuwają strach i lęk. Osoby, które doświadczają przemocy, są często osamotnione i odizolowane od reszty świata. Długotrwałe doświadczanie wszelkich negatywnych i nieprzyjemnych odczuć przez ofiarę może prowadzić do wszelkiego rodzaju zaburzeń zachowania, co wpływa także na codzienne funkcjonowanie prześladowanej jednostki w realnym świecie.

Wszystko, z czym młody użytkownik sieci może spotkać się i czego doświadcza w wirtualnym świecie, w znaczącym stopniu wpływa na sposób jego funkcjonowania w świecie realnym. Może zagrażać to jego rozwojowi emocjonalnemu, psychicznemu czy społecznemu (SzeligiewiczUrban 2016). Możliwe jest m.in. wystąpienie objawów somatycznych, wzrost lęku, a także zwiększenie tendencji do agresji wśród nastolatków. Rośnie także prawdopodobieństwo popełnienia samobójstwa.

\subsubsection{ZABURZENIA ZACHOWANIA}

Zaburzenia zachowania są traktowane jako odbiegające od normy anomalie w sposobie życia jednostki. Wyjaśnienia wciąż wymaga kwestia dokładnego ich sklasyfikowania. Nie jest bowiem oczywiste, czy są one zaburzeniami psychicznymi, czy należy je traktować jako problem społeczny lub wychowawczy. Do objawów powiązanych ze zjawiskiem cyberprzemocy należy: nękanie rówieśników lub innych kolegów oraz znęcanie się nad innymi osobami (Wright, Stern, Phelean 2008). Takie zachowania mogą mieć miejsce zarówno w świecie realnym jak i wirtualnym. Co ważne, zachowania te mogą objawiać się zarówno u ofiar jak i u sprawców elektronicznej agresji.

W klasyfikacji ICD-10 (2002) dokonano podziału zaburzeń zachowania, wyodrębniając: zaburzenia zachowania względem samego siebie, zaburzenia opozycyjno-buntownicze oraz społeczne zaburzenia zachowania (Wright, Stern, Phelean 2008). Zjawisko cyberprzemocy najsilniej powiązane jest $\mathrm{z}$ występowaniem dwóch ostatnich wyżej wymienionych zaburzeń zachowania. Te, klasyfikowane jako opozycyjno-buntownicze, charakteryzują się „drażliwym” nastrojem. Może to wzmagać poziom rozdrażnienia, irytacji czy agresji u nastolatka względem innych użytkowników sieci. Nadwrażliwość wzmaga też tendencje młodego człowieka do prezentowania prowokacyjnych zachowań. Zauważalne może być celowe obrażanie innych, obwinianie ich o swoje błędy i przewinienia (Jerzak 2016).

Doświadczenia nastolatka w świecie wirtualnym mogą także potęgować u niego wzrost agresywności i skłonność do zachowań agresywnych. Cyberprzemoc jest agresją instrumentalną, zaplanowanym działaniem, mającym na celu odniesienie korzyści psychicznych, kosztem skrzywdzenia innej osoby (Kołakowski 2013). Przybiera ona postać słowną, ale jest ukrytą formą agresji, gdyż sprawca liczy na to, że w sieci pozostanie anonimowy. 


\subsubsection{LĘK I OBJAWY SOMATYCZNE}

Napięcie emocjonalne związane z długotrwałym doświadczeniem cyberprzemocy znacząco wpływa na zachowanie osoby. Jest ono związane $\mathrm{z}$ negatywnymi odczuciami jednostki. W następstwie nastolatkowi może zacząć towarzyszyć lęk, możliwe są także napady paniki (Szeligiewicz-Urban 2016). Doświadczana przez długi czas przemoc może uczynić jednostkę bezsilną wobec niej samej. To sprawia, że adolescent często czuje się zagrożony i bezustannie odczuwa silny lęk. U ofiar cyberprzemocy występują także objawy stresu pourazowego (Albański 2010), zwiększona czujność, często osoby te rezygnują z dotychczasowych aktywności, osłabiając także kontakt z rówieśnikami, wycofując się z realnego życia. Osoby doświadczające cyberprzemocy często narażone są na problemy ze snem i trudności z prawidłowym funkcjonowaniem, także w szkole. W badaniu (Sourander, Klomek, Ikonen, Lindroos, Luntamo, Koskelainen, Helenius 2010) wykazano związek zjawiska cyberprzemocy z wystąpieniem u nastolatka bólu głowy czy brzucha. Objawy somatyczne często powinny, zdaniem badaczy, stanowić sygnał do reagowania i pomocy.

Również inne badanie (Kowalski, Limber 2006) wskazuje na bezpośredni związek pomiędzy lękiem społecznym, samooceną a cyberprzemocą. Respondentami byli gimnazjaliści, którzy odpowiadali na pytania dotyczące stosowania cyberprzemocy. Analiza wyników wykazała, że

osoby, które doświadczały cyberprzemocy jednorazowo (lub częściej), miały wyższy poziom lęku społecznego w porównaniu do osób, których ta przemoc nie dotknęła. W przypadku osób, które doświadczały przemocy 2-3 razy w miesiącu, mamy do czynienia z wyższym poziomem lęku społecznego u wszystkich grup. Osoby klasyfikowane w badaniu jako cyberofiary oraz cyberagresorzy wykazywały się również niższą samooceną.

\subsubsection{SAMOBÓJSTWO I DEPRESJA}

Samobójstwa nastolatków powiązanych ze stosowaniem cyberprzemocy często nagłaśniane są przez media. W ostatnich latach mogliśmy usłyszeć o przypadku 14-letniej Anny Halaman z Gdańska. W 2006 roku uczennica gdańskiego Gimnazjum nr 2 popełniła samobójstwo po doświadczeniu jednej z form cyberprzemocy ze strony swoich kolegów z klasy. Podczas lekcji, w trakcie której nieobecna była nauczycielka,, kilkoro chłopaków inicjowało sceny seksualne z jej udziałem. Jeden z oprawców nagrywał całe zdarzenie telefonem komórkowym. Nikt z obecnych w klasie nie powstrzymał oprawców dziewczyny. Nauczycielka dowiedziała się o zajściu z relacji innych uczniów. O całym zdarzeniu poinformowano rodzinę dziewczyny. Telefon ze szkoły odebrał brat, reakcja rodziny nie była jednak właściwa. Dziewczyna ze swoich problemów zwierzyła się również koleżance, wspominając o tym, co zamierza zrobić. Znajoma nastolatki nie potraktowała jej słów poważnie, nie mając świadomości rzeczywistego powodu takiej decyzji. Otoczenie dziewczyny, nieświadome zdarzenia jakie rozegrało się w szkole, zbagatelizowało „wołanie o pomoc” ze strony nastolatki. Dziewczyna popełniła samobójstwo, wieszając się na skakance w swoim pokoju (Szeligiewicz-Urban 2016).

Cyberprzemoc stanowi długoterminowy czynnik ryzyka, prowadzący do chęci popełnienia samobójstwa i pojawienia się depresji u ofiar. W sytuacji bezsilności wobec doświadczanej 
agresji osoby robią krzywdę samemu sobie i stają się agresywne względem innych. Zmniejszone poczucie własnej wartości na skutek długotrwałego doświadczania cyberprzemocy dotyka zarówno dzieci jak i młodzież. Objawy depresji wśród tej grupy osób są coraz silniej wyrażane z wiekiem. Najczęstsze spotykane są objawy somatyczne depresji, rzadziej występują także zaburzenia apetytu i snu(Wright, Stern, Phelean 2008).Nastolatek w okresie dorastania może mieć problem z odpowiednią reakcją na sytuacje stresowe. Jest on wyjątkowo wrażliwy na słowa krytyki skierowane $\mathrm{w}$ jego stronę, może mieć więc kłopot $\mathrm{z}$ odpowiednią reakcją na krytykę, także w Internecie (Jerzak 2016). Z sytuacje mogą zwiększyć prawdopodobieństwa popełnienia samobójstwa przez młodą osobę w sytuacji doświadczania długotrwałego osądu ze strony innych. Nastolatek, będąc aktywnym użytkownikiem sieci, bezustannie narażony jest na ocenę i krytykę ze strony innych. Opiniowanie, anonimowa krytyka czy przejawy jawnej niechęci względem innych, tak powszechne w świecie wirtualnym, w sposób bezpośredni mogą wpływać na stan emocjonalny młodej, rozwijającej się jednostki.

Sytuacja mająca miejsce w internecie jest dla wielu młodych ludzi na tyle stresująca, że często czują się bezsilni, decydują się na drastyczną formę rozwiązania problemu. W momencie osamotnienia i strachu wywołanego przez długotrwałą cyberprzemoc, nastolatek decyduje się popełnić samobójstwo. Prześladowany jest osamotniony, odczuwa lęk i ma poczucie, że został sam z problemem.

\subsection{PODSUMOWANIE}

Dorastający nastolatek $\mathrm{w}$ świecie wirtualnym narażony jest na wiele niebezpieczeństw, w bezpośredni sposób wpływających na jego funkcjonowanie w realnym świecie. Cyberprzemoc dotyka coraz większej liczby młodych ludzi, zagrażając ich prawidłowemu rozwojowi. Ponadto wiedza nastolatków na temat szkodliwości działań w sieci wciąż jest znikoma. Internet może być wykorzystywany przez młodych ludzi nie tylko jako źródło komunikacji, ale także jako środek realizacji zachowań agresywnych wobec innych osób. Zmiany w zachowaniu, wzrost agresywności, występowanie zaburzeń somatycznych i wzrost lęku to tylko niektóre z konsekwencji zjawiska. Szerząca się fala samobójstw na skutek doświadczania cyberprzemocy sprawia, że jest to zjawisko bezpośrednio zagrażające zdrowiu i życiu młodego człowieka.

\section{CYBERPRZEMOC I JEJ KONSEKWENCJE - MODELE WYJAŚNIAJĄCE}

Cyberprzemoc dotyka młodzież w wieku szkolnym, będąc także czynnikiem ryzyka w okresie dorastania. Wpływa na powstawanie zaburzeń utrudniających prawidłowe funkcjonowanie nastolatka. Długotrwałe doświadczanie cyberprzemocy jest sytuacją trudną i wpływającą na jego codzienne funkcjonowanie, zwiększa poziom stresu i odczuwanego lęku. W modelu podatności na stres okazuje się, że jest on czynnikiem współdziałającym w tworzeniu zaburzeń (Sęk 2008). Wpływa na wiele aspektów życia nastolatka, dlatego tak ważne jest to, by poznać konsekwencje, jakie ze sobą niesie. Szczegółowa analiza negatywnych, szkodliwych dla zdrowia następstw jest niezbędna, by móc chronić i wspomagać prawidłowy rozwój młodzieży. Warto więc przeanalizować podłoże i przebieg negatywnych dla zdrowia skutków zjawiska. 
Długotrwale doświadczana cyberprzemoc może prowadzić do zaburzeń w zachowaniu jednostki. Nasilony lęk i współwystępowanie objawów somatycznych stanowi zagrożenie dla zdrowia i rozwoju nastolatka. Doznawanie krzywdy w świecie wirtualnym bardzo często jest czynnikiem bezpośrednio zagrażającym zdrowiu jednostki. Wzmacnia poczucie silnego dyskomfortu, powodując depresję. Wzrost tendencji samobójczych w grupie nastolatków to niepokojąca konsekwencja, która budzi wiele obaw. Dlatego tak ważne jest przeanalizowanie wszystkich aspektów zagadnienia.

Cyberprzemoc może wpływać na realizację zadań rozwojowych, takich jak: uczenie się czytania i pisania, poznawanie pojęć, a także naukę akceptowania własnej fizyczności w okresie adolescencji (Lędzińska, Czerniawska 2011). U ofiar cyberprzemocy mogą wystąpić zaburzenia zachowania, lęk, depresja, a także wzrost tendencji samobójczych. Doświadczanie cyberprzemocy może potęgować wzrost agresywności, wpływać na zmianę zachowania względem rówieśników i sprawiać, że nastolatkowie częściej stają się jej sprawcami. Rozwój młodego człowieka związany jest z doświadczeniami jednostki i reakcją otoczenia na te doświadczenia. Wszelkie możliwości i pragnienia młodego człowieka są konfrontowane z wymaganiami otoczenia, co stanowi źródło kryzysu w procesie budowania tożsamości dojrzewającej osoby (Harwas-Napierała, Trempała 2004).

Teoria zadań rozwojowych Roberta J. Havighursta (1981) oraz teoria rozwoju psychospołecznego E. Eriksona (2004) to dwie spośród teorii rozwojowych, które mam zamiar wykorzystać do opisania związku doświadczanej cyberprzemocy z rozwojem młodego człowieka. Ważne z punktu widzenia rozwoju jest dostrzeżenie powiązań pomiędzy światem wirtualnym a realizacją zadań rozwojowych, czy kształtowaniem się tożsamości.

Psychologia rozwojowa zajmuje się opisem i wyjaśnieniem zmian, mających miejsce w trakcie trwania życia człowieka. Rozwój to proces trwający od chwili poczęcia aż do śmierci. Rozumiany jest jako wzrost czynności, funkcji lub procesów psychicznych, a także wszelkich zmian w tym zakresie. Ujmowany jest w kategoriach celów, zadań życiowych oraz ról, jakie pełni jednostka w trakcie trwania życia. Podstawowym zadaniem psychologów rozwojowych jest opisanie znaczenia każdej ze zmian rozwojowych. Wskazują oni, czym jest zmiana, czym charakteryzuje się rozwój, czym dana zmiana przejawia się oraz w którym momencie życia może zaistnieć, po czym następuje, jakie zachowanie może poprzedzać daną zmianę. Wyjaśnień tych poszukuje się zarówno w uwarunkowaniach środowiska życia jednostki jak i w czynnikach wewnętrznych (Harwas-Napierała, Trempała 2004).

W oparciu o teorię frustracji agresji pokażę przyczyny wystąpienia zachowań agresywnych u nastolatków. Bezsilność wobec negatywnych doświadczeń w sieci może wzmagać u nastolatka poczucie frustracji wynikające $\mathrm{z}$ zablokowania możliwości osiągnięcia celu, jakim jest uwolnienie się od oprawcy (Zimbardo, Gerrig 2008). Doświadczana cyberprzemoc wzmaga tendencje do zachowań agresywnych, sprawiając, że często ofiary same stają się jej sprawcami. 


\subsection{MODEL PODATNOŚCI - STRES}

Długotrwałe doświadczanie cyberprzemocy i związany z tym stres może prowadzić do wystąpienia zaburzeń zarówno u jej ofiar, jak i u sprawców. Wpływając na zachowanie jednostki, powoduje zaburzenia lękowe czy depresje, a także prowadzi do wzrostu agresji. W konsekwencji może sprawić, że ofiara cyberprzemocy może stać się jej sprawcą w przyszłości. Model podatności na stres wyróżnia trzy czynniki, które mogą wpływać na powstawanie zaburzeń w funkcjonowaniu. Są to: czynniki biologiczne, psychologiczne i społeczno-kulturowe, będące predyspozycjami jednostki. Są one ważne, ale nie są bezpośrednimi sprawcami zaburzeń, których pojawienie się generowane jest również przez oddziałujące czynniki stresujące (Sęk 2008). Dotyczy to zarówno ofiar jak i sprawców cyberprzemocy. Trudno jednak jednoznacznie stwierdzić, czy powstawanie zaburzeń ma jedną przyczynę, czy też jest ich wiele. Zwiększona podatność na stres i ujawnienie się zaburzeń depresyjnych nasila się szczególnie w momencie doświadczania przez nastolatka kryzysu rozwojowego, kiedy to ma do czynienia z osłabioną odpornością swojego organizmu. Model podatności na stres wyróżnia psychospołeczne i fizyczno-biologiczne czynniki stresu. Stresory te mogą pochodzić z otoczenia, ale mogą także mieć swoje źródło w psychice oraz wynikać z relacji człowieka i otoczenia. Źródłem stresu mogą być zarówno sytuacje życiowe, napięcie wewnętrzne lub zewnętrzne. Doświadczanie cyberprzemocy jest z pewnością dla nastolatka źródłem stresu. Istotne jest to, jak adolescent ocenia dane wydarzenie w swoim życiu, a także to, w jaki sposób uczy się funkcjonować w nowej rzeczywistości (Sęk 2008).

W zależności od predyspozycji jednostki mamy do czynienia z innym poziomem lęku i ryzykiem występowania zaburzeń depresyjnych. O pogorszeniu stanu zdrowia w konsekwencji doświadczanego stresu decyduje m.in. stan somatyczny organizmu. Na skutek długotrwale doświadczanej cyberprzemocy nastolatek może odczuwać silne bóle głowy, mieć problemy ze snem. Model podatności na stres podkreśla, że ludzie posiadają także wiele mechanizmów obronnych, zwiększających ich odporność na stres. Uogólnionymi zasobami odpornościowymi są właściwości jednostki i środowiska, pozwalające uniknąć stresorów. Najbardziej rozbudowaną grupą zasobów są właściwości psychiczne człowieka. Ważne jest poczucie tożsamości, której ukształtowanie poprzez doświadczanie cyberprzemocy może być utrudnione. Zasoby działają niezależnie od sytuacji, w jakiej znalazła się jednostka i pozwalają zniwelować napięcie wynikające z negatywnych doświadczeń. Aktywują się, kiedy nastolatek ma problem z realizacją zadań, bądź gdy wymagania ze strony społeczeństwa przerastają jego możliwości. Realizacja zadań rozwojowych jest kluczowym warunkiem do dalszego prawidłowego rozwoju. Istotne dla jednostki jest to, że musi ona zakończyć każde zadanie, by przejść do kolejnego etapu rozwojowego (Becelewska 2006).

\subsection{ZADANIA ROZWOJOWE WEDŁUG R. HAVIGHURSTA}

Treść zadań rozwojowych, przed jakimi staje jednostka, wiąże się ze zmianami, jakie zachodzą w jej organizmie, a także zmianami w środowisku społecznym. Związane jest to z kompetencjami, z jakimi jednostka kończy poszczególne etapy rozwoju w ciągu życia. Ważne są posiadane 
przez człowieka aktualne zasoby, związane z tym, jak radził on sobie w trudnych sytuacjach życiowych. Kolejne zadania rozwojowe, jakie stawia się jednostce, są rezultatem rozbieżności pomiędzy kompetencjami jednostki a naciskiem ze strony środowiska zewnętrznego na przejście do kolejnego etapu rozwojowego. To, jakie zadanie rozwojowe podejmie człowiek, a także to, jaki wybierze sposób realizacji każdego z zadań w ciągu życia, jest kwestią indywidualną. Wpływa to na wytwarzany przez człowieka obraz samego siebie (Brzezińska 2000). Ostatecznie rozwiązanie zadań rozwojowych w kolejnych etapach życia umożliwia wejście jednostki w kolejny etap rozwojowy (Ledzińska, Czerniawska 2011). Havighurst (1981) wyróżnił 6 faz rozwojowych, w których jednostka zdobywa nowe umiejętności i kompetencje, realizując stawiane jej zadania na poszczególnych etapach życia. Wyróżnił: okres niemowlęcy, trwający od momentu narodzin do 1.roku życia dziecka; dzieciństwo, przypadające pomiędzy 2. a 3.rokiem życia; okres zabawy między 4. a 5. rokiem życia; wiek szkolny, który, zgodnie z koncepcją autora teorii zadań rozwojowych, jest okresem przypadającym pomiędzy 6. a 12. rokiem życia; okres adolescencji, tj. czas pomiędzy 13. a 22. rokiem życia. Owe fazy rozwojowe są znaczące z punktu widzenia problemu opisanego w artykule, dlatego warto przeanalizować poszczególne zadania, jakie jednostka zobowiązana jest realizować na poszczególnych etapach życia.

W wieku szkolnym jednostka uczy się swojej roli płciowej. Niezbędny jest także rozwój umiejętności potrzebnych w szkole, takich jak: czytanie, pisanie, liczenie czy przyswojenie pojęć niezbędnych w codziennym życiu. Zadaniem jednostki w tym okresie jest także próba osiągnięcia niezależności osobistej, czyli poczucia wolności (Brzezińska 2000).

W okresie wczesnej adolescencji, pomiędzy 13. a 17. rokiem życia, zaczynają kształtować się związki z rówieśnikami. Młody człowiek uczy się akceptować swą fizyczność, starając się jednocześnie zdobyć niezależność emocjonalną. Opanowuje też swoją rolę w społeczeństwie, związaną z jego płcią. Głównym zadaniem, jakie stawiane jest przed jednostką w tym okresie, jest wybór zawodu, tym samym osiągnięcie niezależności finansowej i ekonomicznego bezpieczeństwa. Młody człowiek w okresie późnej adolescencji pomiędzy 18. a 22. rokiem życia ma przede wszystkim przygotować się do życia rodzinnego i małżeństwa, rozwija się także pod względem intelektualnym, nabywając nowe, obywatelskie umiejętności. Wzbogaca także swoje życie o nowy system wartości. Po zakończeniu tych etapów rozwoju jednostka wchodzi w fazę dorosłości. Havighurst (1981) wyróżnia fazę wczesnej, średniej i późnej dorosłości.

Długotrwale doświadczana cyberprzemoc może negatywnie wpływać na realizację zadań rozwojowych w szczególności w wieku szkolnym oraz w okresie adolescencji. Dotyczy to zarówno sprawców jak i ofiar zjawiska. Nastolatkowie będący ofiarami cyberprzemocy, częściej akceptują przejawy przemocy, przez co sami stają się częściej jej sprawcami. Nastolatek kształtuje swoje sumienie, moralność, własny system wartości oraz rozwija swoją postawę wobec grup i instytucji, których jest częścią (Ledzińska, Czerniawska 2011). Styczność z agresją w świecie wirtualnym może zaburzyć prawidłową realizację tego zadania. Dodatkowo w późniejszym etapie rozwoju dorastający młody człowiek staje się w pełni odpowiedzialny za swoje zachowania. Kształtuje wartości, które od teraz stają się podstawą jego funkcjonowania. 
Negatywne doświadczenia w świecie wirtualnym mogą zaburzyć sferę odpowiedzialności za zachowanie, dają bowiem perspektywę anonimowości. Wszystko, czego jednostka doświadczyła w wieku szkolnym na tym etapie, jest ugruntowane i stanowi podstawę dalszego rozwoju.

$\mathrm{Na}$ realizację zadań rozwojowych i rozwijający się organizm nastolatka wpływ mają naciski ze strony otoczenia oraz potrzeby człowieka, takie jak samoocena, aspiracje, emocje. Wykonanie poszczególnych zadań jest dla nastolatka źródłem satysfakcji, daje poczucie spełnienia czy dumy. W przypadku niemożności wykonania któregokolwiek z zadań jednostka zaczyna odczuwać napięcie, które może rodzić poczucie frustracji.

Niemożność opanowania istotnych dla rozwoju umiejętności często staje się także powodem zaniżonej samooceny, wiąże się z niską oceną ze strony społeczeństwa. Radzenie sobie z przeszkodami utrudniającymi realizację zadań rozwojowych jest dla nastolatka znacznie łatwiejsze, kiedy otrzymuje on dostateczne wsparcie społeczne. Jeśli jednak nie jest ono jednostce dostarczane, zaczyna ona radzić sobie z napięciem i frustracją uciekając się do negatywnych dla zdrowia działań, takich jak: nałogi, agresja, czy wyniszczająca dieta.

Młoda osoba doświadcza cyberprzemocy związanej ze zmianami w zachowaniu, częstszym poczuciem irytacji i rozdrażnienia, wzrostem lęku oraz obniżoną samooceną, a w efekcie naznaczeniem lub wykluczeniem społecznym. Cyberprzemoc jest często przyczyną jak i skutkiem negatywnego oddziaływania grupy rówieśniczej na jednostkę - presji. Negatywna presja rówieśnicza prowadzić może do depresji, nieumiejętności radzenia sobie ze stresem, zaburzenia więzi społecznych, czy nawet samobójstw, prowadząc tym samym do uniemożliwienia realizacji zadań rozwojowych (Ponczek, Olszowy 2012).

\subsection{TEORIA ROZWOJU PSYCHOSPOŁECZNEGO WEDŁUG E. ERIKSONA}

Rozwój psychospołeczny człowieka wynika z interakcji między wewnętrznym światem jednostki, a zewnętrznymi wymaganiami społeczno-kulturowymi, z którymi musi się zmagać (Bee, Boyd 2008). Człowiek, by w pełni wykształcić swoja tożsamość, powinien przejść przez osiem kryzysów, każdy z nich posiada strategie rozwiązania. Każdy z nich jest także wynikiem nowych zadań czy relacji, które stanowią dla jednostki wyzwanie. Kryzys doświadczany przez jednostkę na każdym etapie jej rozwoju często wiąże się z radykalną zmianą perspektywy (Erikson 2004). Pozytywne rozwiązanie kryzysu nie zawsze jest równoznaczne z pozytywnym zakończeniem danego etapu rozwoju, ale może prowadzić do wewnętrznego wzbogacenia jednostki o nowe wartości. Zdaniem Eriksona (2004) każdy okres w rozwoju człowieka definiowany jest przez parę przeciwności, takich jak: postawa ufności a postawa nieufności, autonomia a wstyd i zwątpienie, inicjatywa a poczucie winy.

Kryzys dotykający dziecko w wieku szkolnym opiera się na związku między pracowitością a poczuciem niższości. Pozyskiwaną przez jednostkę wartością jest kompetencja. To na tym etapie rozwoju wskazuje się często u dzieci tendencje do uzależnienia od narzuconych obowiązków, dlatego tak ważne jest by, zachęcać je do odkrywania, uczenia się w zupełnie nowy sposób, niekoniecznie wynikający jedynie z obowiązku. Wchodząc w wiek szkolny pomiędzy 6. a 12. rokiem życia, dziecko kształtuje w sobie poczucie pracowitości, nabiera 
zdolności do perfekcyjnego wykonywania powierzonych mu czynności, by czuć się użytecznym. Poczucie niższości może wynikać z nierozwiązanych wcześniej konfliktów dziecko chce być traktowane jak wcześniej, jednocześnie porównuje się z innymi, doznając w tym względzie poczucia niższości. Rodzina niedostatecznie przygotowała dziecko na życie szkolne, które może okazać się źródłem jego rozczarowań, kiedy to okaże się, że zdobyta wcześniej wiedza nie jest wystarczająca, by sprostać np. wymaganiom nauczyciela. W tym okresie rozwoju tylko odpowiednio wcześnie rozbudowane możliwości dziecka mogą być przez niego wykorzystywane.

Napięcie między tożsamością a niepewnością roli jest głównym dylematem okresu dojrzewania. Wiąże się $\mathrm{z}$ ponownym rozważeniem posiadanej $\mathrm{w}$ danym momencie tożsamości, ponownym zintegrowaniem pojęcia samego siebie oraz przystosowaniem do zmian zachodzących w organizmie. Czynnikiem kryzysogennym w tym okresie może być nadmiar możliwości wyborów, dostępnych dla jednostki w tym okresie (Bee, Boyd 2008). „Cnotą” ułatwiającą poszukiwanie nowych wartości jest wierność. To także czas, w którym dojrzewający nastolatek próbuje umocnić swoją rolę w społeczeństwie, koncentrując się na tym, co myślą o nim inni (Erikson 2004). Adolescent kształtuje swoje poczucie rzeczywistości i musi być przekonany o tym, że jego sposób doświadczania był wykorzystywany także przez innych. Poczucie tożsamości ego jest bowiem podtrzymywane przez ciągłość i niezmienność, a także przez świadomość własnej wartości w oczach innych. Rozproszenie tożsamości następuje w momencie, w którym jednostka nie potrafi ustalić swojej tożsamości, a jednocześnie istnieje zbyt wielki nacisk społeczny w kierunku jej skonstruowania.

Erikson (2004) wyróżnił także kryzysy związane z napięciami między intymnością a izolacją, kreatywnością a stagnacją oraz integralnością ego a rozpaczą.

Wchodząc w wiek szkolny, nastolatek wkracza w nowe środowisko, ma styczność z rówieśnikami. Zgodnie z teorią Eriksona główne zadanie, będące źródłem kryzysu na tym etapie rozwoju, to przyswojenie podstawowych umiejętności i kulturowych norm (Bee, Boyd 2008). Wystąpienie zaburzeń zachowania, związane z długotrwałym doświadczeniem cyberprzemocy, w znacznym stopniu zakłóca stopień przystosowania się do norm obowiązujących w środowisku. Wszelkie zmiany w zachowaniu dotyczą zarówno ofiar jak i sprawców zjawiska, gdyż wydarzenia ze świata wirtualnego oddziałują na każdego. Ofiary często prowokują agresywne zachowania, zaś sprawcy stają się nerwowi, co utrudnia im prawidłowe funkcjonowanie. Cyberprzemoc może także mieć związek z wystąpieniem kryzysu w inicjalnym okresie dojrzewania. Wtedy to wówczas nastolatek poszukuje swojej tożsamości, chce uzyskać poczucie wspólnoty z innymi, także w wirtualnym świecie. Staje się często nietolerancyjny, odrzucając wszystkich tych, którzy w jakiś sposób się od niego różnią. Jego zdaniem to na przykład kolor skóry czy sposób ubioru decydują o przynależności do grupy (Erikson 2004).

Wiek dorastania związany jest $\mathrm{z}$ wieloma przemianami w organizmie i w życiu jednostki. Osiągniecie tożsamości wiąże się z ukształtowaniem własnego systemu wartości oraz przystosowaniem do funkcjonowania w świecie poprzez tworzenie związków z innymi, pracę czy sposób spędzania wolnego czasu. Nastolatek, chcąc sprostać wymaganiom społecznym 
związanym z rozwiązaniem kryzysu w czasie dojrzewania, może odczuwać lęk, bezradność oraz strach przed odrzuceniem przez znaczące osoby. Adolescent zmaga się wówczas z dylematem dotyczącym formowania się własnej tożsamości, tj. obrazu siebie samego. Młody człowiek identyfikuje się z grupą, decydując do której z nich chce przynależeć i jakie miejsce w niej zajmować. W tej sytuacji często zmaga się z różnego typu wyzwaniami, co może powodować u niego stres i napięcie. Stabilne, wspierające otoczenie pozwala jednostce na ostateczne uformowanie się tożsamości (Ponczek, Olszowy 2012).

Poszukiwanie tożsamości w wieku dorastania często przenosi się także do świata wirtualnego. Sieć jest przestrzenią, w której nastolatkowie łatwo mogą eksperymentować i bez przeszkód kształtować dowolną tożsamość. W badaniach przeprowadzonych w ramach projektu EU Kids Online (2011) przeanalizowano sposoby kształtowania się tożsamości w internecie, a więc podawanie $\mathrm{w}$ sieci wieku innego niż rzeczywisty oraz tożsamość wirtualną, jako tożsamość odmienną od prezentowanej przez nastolatka w realnym świecie. Wyniki badania pokazały, że wiek inny niż rzeczywisty podawało 3,2\% spośród przebadanych nastolatków, dodatkowo aż 38,1\% osób „czuje się bardziej sobą” dzięki tożsamości, jaką wykreowało w internecie. Zauważono, że jeśli kreowanie tożsamości w internecie ma związek z realizacją zadań rozwojowych $\mathrm{w}$ tym zakresie, tendencja ta powinna rosnąć wraz z wiekiem. Wyniki potwierdziły, że tak się dzieje. W trakcie eksperymentowania z tożsamością wirtualną ryzyko doświadczenia negatywnych czynników wzrasta. Według przeprowadzonych badań ci nastolatkowie, którzy udawali w internecie kogoś, kim nie są, częściej mieli negatywne doświadczenia emocjonalne związane z treściami, z jakimi zetknęli się w sieci. Okazywali się oni także sprawcami wrogich zachowań wobec innych. Znacznie częściej wysyłali innym wiadomości o wydźwięku seksualnym oraz prezentowali zachowania agresywne wobec innych (Kirwil 2011). Eksperymentowanie z tożsamością w sieci wiąże sięz konsekwencjami w postaci negatywnych doświadczeń emocjonalnych, agresją wobec innych użytkowników i z nadmierną ciekawością dotyczącą treści seksualnych. Przeprowadzone badania potwierdzają, iż dzieci, które eksperymentują ze swoją tożsamością, są mniej bezpieczne w sieci.

Teoria Eriksona wyznaczała intymność jako kryzys w okresie dorosłości, jednakże badania związku intymności z występowaniem depresji prowadzono na grupie nastolatków. Intymność jest definiowana jako zdolność do partnerstwa i zaangażowania w związki. W badaniach Williams'a Connolly'ego i Segala (2001) analizowano podatność na depresje w grupie nastolatków. Wyniki wskazują, że dorastające dziewczyny, które doświadczyły niskiego poziomu intymności w związku, mogą częściej odczuwać negatywny nastrój. Był on także powiązany z występowaniem epizodu depresyjnego, co stanowi czynnik ryzyka depresji w późniejszych latach życia. Z kolei w badaniach przeprowadzonych przez Mackinnona, Nosko, Pratta i Norrisa (2011) w oparciu o model rozwoju psychospołecznego Eriksona (2004) przeanalizowano pozytywny związek między intymnością a generatywnością. Intymność, zarówno ta związana ze związkiem jak i z przyjaźnią, przyczyniła się do zwiększenia poczucia niepokoju niezależnie od pozostałych czynników. Potwierdził się także pozytywny związek pomiędzy intymnością a troską o generatywność w przyszłości. Pozytywne doświadczenia z 
intymnymi związkami mogą ułatwić jednostce rozwiązanie dylematu związanego z bliskością i izolacją.

Dojrzała zażyłość i związki intymne mogą wskazywać na rozwiązanie kryzysu psychospołecznego związanego z niepewnością roli. Stanowi to poparcie dla teorii rozwoju psychospołecznego Eriksona (2004) na różnych etapach rozwoju (Marasco 2012).

W teorii rozwoju psychospołecznego rozwój człowieka wyznaczany jest przez biologiczne czynniki popędowe oraz interakcje społeczne (Przetacznik Gierowska, Tyszkowa 1996). Zdaniem Havighursta (1981) na realizację zadań rozwojowych wpływ mają: oczekiwania społeczne, różnice indywidualne związane $\mathrm{z}$ rozwojem organizmu oraz preferowane indywidualne wartości. W teorii Eriksona (2004) człowiek w przypadku rozwiązania każdego z rozwojowych dylematów wpływających na kształtowanie tożsamości zyskuje cnoty, takie jak: nadzieja, wola, zdecydowanie, kompetencje, wierność, miłość, opiekuńczość, mądrość. Rozwiązanie zadań rozwojowych zdaniem Havighursta (1981) pozwala jednostce na zyskanie nowych sprawności motorycznych, emocjonalnych i społecznych. Obie koncepcje koncentrują swoją uwagę na prawidłowym rozwoju człowieka, wskazując na trudności i zmagania, z którymi każda jednostka musi się zmierzyć, by w pełni wykształcić swoją indywidualną tożsamość i osobowość. W przypadku obu teorii wskazuje się na to, iż przejście przez każdy z etapów rozwoju oraz pomyślna realizacja poszczególnych zadań wiążą się z konsekwencjami, dlatego też warto zestawić ze sobą obie koncepcje rozwojowe.

Wiedza o zadaniach rozwojowych oraz pomoc w ich zrealizowaniu w razie konieczności może być pomocna $\mathrm{w}$ procesie wychowywania młodego człowieka. Jest też istotna $\mathrm{z}$ punktu widzenia analizy problemu cyberprzemocy wśród nastolatków. Zdarzenia ze świata wirtualnego w znaczący sposób wpływają na sposób wykonywania zadań powiązanych z rozwojem organizmu, dlatego tak ważna jest pogłębiona analiza ich znaczenia w życiu jednostki. Podejmowanie trudu realizowania poszczególnych zadań rozwojowych umożliwia przejście do kolejnej fazy rozwoju. Kryzys może pojawić się, kiedy jednostka staje przed nowymi zadaniami i przechodzi do kolejnego etapu swojego życia. Ma on charakter dwubiegunowy i zawsze posiada dwa rozwiązania. Jedno z nich jest korzystne dla jednostki, drugie zaś negatywne i stanowi źródło napięcia. Koncepcje Eriksona i Havighursta (1981) są koncepcjami rozwojowymi, które stworzono po to, by opisać przebieg ludzkiego życia, dzieląc je na poszczególne etapy. Obejmują one swym zasięgiem cały okres życia człowieka, od narodzin aż do śmierci, ukazując zmagania jednostki na poszczególnych etapach rozwoju. Zarówno Havighurst (1981), jak i Erikson (2004),w swoich teoriach rozwoju człowieka ukazują prawidłowe wzorce zachowania, które kształtują zdrową jednostkę. Obie koncepcje koncentrują uwagę na potrzebach, które człowiek posiada i chce zaspokajać na poszczególnych etapach swojego życia. Obie te koncepcje ukazują także konsekwencje i negatywne skutki dla zdrowia i kształtowania tożsamości młodego człowieka.

Widoczną konsekwencją cyberprzemocy jest wzrost tendencji do zachowań agresywnych względem otoczenia i rówieśników. Często agresja bywa traktowana jako zaburzenia zachowania - czyli jedno z negatywnych następstw cyberprzemocy. Należy jednak pamiętać, 
że w diagnostyce są to odrębne od siebie zjawiska (Kołakowski 2013).

\subsection{TEORIA FRUSTRACJI-AGRESJI}

Wzrost poziomu agresji dotyczy zarówno ofiar jak i sprawców cyberprzemocy. Sprawcy często nie potrafią radzić sobie $w$ trudnych sytuacjach, co potęguje uczucie frustracji. Agresorzy przejawiają chęć dominacji nad rówieśnikami. W przypadku ofiar cyberprzemocy charakterystycznym zachowaniem młodzieży może być wprowadzanie zamieszania, niepokoju i prowokacja konfliktu w grupie rówieśniczej, częściej wykazują też lęk społeczny i obniżenie nastroju (Kowalski, Limber, Agatston 2010).

Agresja dla sprawców cyberprzemocy stanowi narzędzie służące do osiągnięcia zamierzonego celu, czyli do wyrządzenia fizycznej lub psychicznej krzywdy innym ludziom. Czynnikiem zwiększającym prawdopodobieństwo wystąpienia zachowania agresywnego jest frustracja. Ma ona miejsce, gdy nie można osiągnąć ważnego celu, w związku z czym może wzbudzać agresję oraz niechęć przeciwko jej źródłu (Farnicka, Liberska, Niewiedział 2016). Jest też stanem wewnętrznym, będącym reakcją na napotkanie przeszkody (Wojciszke 2006). Im większy jest jej poziom, tym bardziej zwiększa się prawdopodobieństwo wystąpienia agresji. Sama frustracja nie jest często wystarczająca, bowiem w przypadku wywołania zachowania agresywnego występują jeszcze inne czynniki, tak zwane sygnały wywoławcze. Są to bodźce związane z wystąpieniem gniewu, do którego wystarczy wywołanie negatywnych emocji.

Niektóre z przejawów zachowań agresywnych nie są wynikiem frustracji, ich podstawą mogą być także inne motywy stanowiące część ludzkiego życia. Związek między nieprzyjemnym doświadczeniem a reakcją nastolatka zależy od przypisania cech temu, co wywołało to doświadczenie. To, czy zachowanie agresywne może zaistnieć, zależy od wcześniejszych doświadczeń jednostki.

Wspomnienia nieprzyjemnych zdarzeń ze świata wirtualnego wywołują negatywne myśli i uczucia, zwiększając tym samym prawdopodobieństwo wystąpienia zachowań agresywnych. Są one często reakcją na określone sytuacje, co być zaświadcza o tym, że są to działania podejmowane pod wpływem emocji (Zimbardo, Gerrig 2008). Długotrwałe doświadczanie przemocy w internecie może wywoływać napięcie emocjonalne, będące źródłem dyskomfortu psychicznego jednostki, niezwiązanego $\mathrm{z}$ frustracją. Zachowanie powstające na skutek długotrwałego doświadczania cyberprzemocy, bądź też nieskutecznej próby skrzywdzenia drugiej osoby może powodować wzrost agresji wśród adolescentów.

Frustracja zawsze wywołuje agresję, choć nie zawsze jest ona skierowana na cel wywołujący daną frustracje (Wojciszke 2006). Niechęć i złość wywołana przez jakiś czynnik, na przykład kłopoty w kontaktach z rówieśnikami w realnym świecie, mogą spowodować wystąpienie zachowań agresywnych w przestrzeni wirtualnej. Strach przed karą za swoje postępowanie może być czynnikiem hamującym zachowania agresywne, jednakże internet daje użytkownikowi poczucie anonimowości, na skutek czego oprawcy często czują się bezkarni. Może to potęgować występowanie zachowań agresywnych, gdyż to właśnie obserwacja kogoś zachowującego się w sposób niewłaściwy może wzmagać tendencje zachowań agresywnych (Albański 2010). 


\subsection{PODSUMOWANIE}

W wieku szkolnym w życiu i w organizmie młodego człowieka zachodzi bardzo wiele zmian związanych $\mathrm{z}$ wchodzeniem $\mathrm{w}$ kolejny etap rozwoju i nowe szkolne środowisko. Zmienia się sposób postrzegania samego siebie, ale przede wszystkim postrzeganie innych ludzi. Nastolatek częściej koncentruje swoją uwagę na cechach wewnętrznych i wartościach, jakie są prezentowane przez innych. W tym okresie rozwoju coraz częściej zaczynają pojawiać się zachowania agresywne. Mogą być one także odpowiedzią na negatywne doświadczenia w świecie wirtualnym. Pozorny brak odpowiedzialności za poczynania $\mathrm{w}$ internecie również może skłaniać do prezentowania zachowań agresywnych. Świadomość wielu obserwatorów czy współsprawców przemocy może prowadzić do osłabienia odpowiedzialności i poczucia winy za swoje czyny (Albański 2010).

W wieku szkolnym dziecko zaczyna kształtować poczucie własnej wartości. Duże znaczenie ma poziom akceptacji przez rówieśników, a także przynależność do grupy. Dzieci odrzucone przez grupę rówieśniczą często prezentują zachowania agresywne, mogą mieć także problem z kontrolowaniem własnych emocji (Bee, Boyd 2008). W okresie dorastania prawidłowo rozwijający się człowiek zmaga się z kryzysem swojej tożsamości. Szukając jej, jednostka staje się niepewna swojej dotychczasowej roli. Dorastający nastolatek przynależący do grupy rówieśniczej, często staje się nietolerancyjny wobec wszelkich odmienności, co stanowi formę obrony jednostki przed pomieszaniem tożsamości. W sieci jednostka używa portali społecznościowych do budowania własnej tożsamości i relacji z innymi. Często wpływ na ich kształt mają także osoby trzecie. Wiek adolescencji to czas, w którym młode osoby podatne są na wpływy innych, chcą być akceptowane i znajdować się w centrum uwagi, co często kształtuje ich sposób zachowania w świecie wirtualnym (Andrzejewska 2014).

W okresie dorastania bardzo wiele czynników ma wpływ na kształtowanie postaw i funkcjonowanie nastolatka $\mathrm{w}$ realnym świecie. Negatywne następstwa korzystania z internetu i doświadczanie cyberprzemocy są czynnikiem ryzyka zaburzającym prawidłowy rozwój nastolatka. Niezbędne są więc działania prewencyjne w zakresie edukacji i ochrony, aby zapobiec rozprzestrzenianiu się zjawiska cyberprzemocy wśród dorastającej młodzieży.

\section{CYBERPRZEMOC - PROPOZYCJA ODDZIAŁYWAŃ PREWENCYJNYCH}

Konsekwencje związane z długotrwałym doświadczeniem cyberprzemocy mogą przeniknąć do wielu sfer życia nastolatka i zaburzać jego funkcjonowanie w środowisku szkolnym, wpłynąć na jego zdrowie i relacje z rówieśnikami oraz rodziną. Cyberprzemoc negatywnie oddziałuje na poczucie tożsamości adolescenta oraz realizację zadań rozwojowych w okresie dorastania. Przy pomocy programu profilaktycznego, wdrożonego w szkołach oraz realizowanych w jego ramach zadań, wskazane byłoby wyposażenie młodzieży w narzędzia konieczne do ochrony przed szkodliwym działaniem omawianego zjawiska. Należałoby przekazać nastolatkom niezbędną wiedzę dotyczącą cyberprzemocy, a także rozwijać umiejętności, które pomogą w jej skutecznym przeciwdziałaniu. Proponuję stworzenie programu prewencyjnego dotyczącego zjawiska cyberprzemocy. Głównym jego celem jest ochrona dzieci i młodzieży przed szkodliwym 
działaniem oraz edukacja w zakresie właściwego i bezpiecznego korzystania z zasobów internetu. Wszelkie działania w ramach programu podejmowane będą po to, by przeciwdziałać, chronić i zapobiegać szkodliwemu oddziaływaniu zjawiska. Prewencyjny program przeciw cyberprzemocy stworzony został z myślą o praktycznym jego zastosowaniu w szkołach. Szkoły są placówkami odpowiedzialnymi za wspomagania rozwoju dzieci i młodzieży. Młodzież w trakcie nauki rozwija umiejętność współpracy z innymi, uczy się nadawać sens i znaczenie przyswajanym informacjom.

\subsection{ZAŁOŻENIA FORMALNE PROGRAMU}

Za realizację programu profilaktycznego w placówkach dydaktycznych odpowiedzialnie powinny być specjalnie do tego wyznaczone grupy nauczycieli wyspecjalizowane w zakresie problemu cyberprzemocy wśród dzieci i młodzieży. Krok ten pozwoli zwiększyć kontrolę nad przeprowadzanymi działaniami, by w rezultacie były one skuteczniejsze (Monks, Coyne 2012).

Program profilaktyczny, przeznaczony do wykorzystania w szkołach, swoim zasięgiem i działaniami ma obejmować uczniów na dwóch poziomach edukacyjnych. Cyberprzemoc, jako zjawisko będące przedmiotem programu, znacząco wpływa na dwa kluczowe etapy rozwoju - wiek szkolny oraz okres dorastania. Program skierowany będzie do starszych uczniów ze szkoły podstawowej - klas 5. do 8. oraz uczniów szkół ponadgimnazjalnych. W ten sposób dzieci i młodzież będą mogły zetknąć się z tematyką korzystania z internetu i związanych z nimi zagrożeń na różnych etapach swojego rozwoju.

Każda z grup wiekowych weźmie udział w pięciu spotkaniach. Przewidywany czas realizacji założeń programu to $12 \mathrm{~h}$ lekcyjnych. Program realizowany będzie w szkołach przez pięć tygodni w ramach zajęć pozalekcyjnych. Dwa ostatnie spotkania w ramach programu przewidują także możliwość dobrowolnego udziału rodziców uczniów. Takie działanie ma na celu zachęcenie opiekunów do aktywnego udziału w realizacji programu chroniącego zdrowie i rozwój ich pociech.

Tematy stanowiące zakres spotkania $\mathrm{w}$ obu grupach nie będą się różnić, ale poziom realizowanych zadań w ramach programu dostosowywany będzie do grup wiekowych, w których prowadzone będą poszczególne spotkania, tak by dopasować poziom do norm rozwojowych dzieci. Spotkania dotyczyć będą zjawiska cyberprzemocy i bezpieczeństwa w sieci. Uczniowie podczas zajęć poznają definicję, formy i drogi rozpowszechniania cyberprzemocy. Zapoznają się także $\mathrm{z}$ sylwetkę sprawcy i ofiary oraz z konsekwencjami i sposobami zapobiegania zjawiska internetowej agresji. Każde ze spotkań podzielone zostało na dwie części. W każdej z nich, w ramach zadań wykonywanych przez uczniów, omawiane będą poszczególne zagadnienia z zakresu cyberprzemocy. Forma zajęć podczas trwania programu profilaktycznego dostosowywana będzie do grupy wiekowej, z którą nauczyciel w danym momencie pracuje.

\subsection{SPOTKANIE 1.}

Pierwsze spotkanie w obu grupach wiekowych będzie spotkaniem wprowadzającym w tematykę 
cyberprzemocy. Jego celem jest zapoznanie młodzieży ze zjawiskiem cyberprzemocy - jej obrazu prezentowanego w filmach, a także poznanie stanu wiedzy współczesnych nastolatków na temat bezpieczeństwa i zagrożeń w sieci. Pierwsze zajęcia będą trwać cztery godziny lekcyjne. Pierwsza część spotkania w obu grupach będzie poświęcona na projekcję filmu dotyczącego zjawiska cyberprzemocy. Dzieci i młodzież ponadgimnazjalna podczas oglądania zapisuje osobiste refleksje. Nauczyciel może zadać im pytania pomocnicze, w celu przekazania wskazówek. Mogą być to pytania, typu: „Co zaciekawiło cię najbardziej podczas oglądania filmu?”, „Jak zachowywał się główny bohater?”, „Jak zachowywali się jego koledzy/otoczenie?”

W drugiej części uczniowie dzielą się między sobą refleksjami i spostrzeżeniami po obejrzeniu filmu. Sposób realizacji tego zadania będzie różny w zależności od grupy, z którą nauczyciel aktualnie pracuje. W klasach 5-8 szkół podstawowych uczniowie tworzą w grupach kolaże prezentujące obraz cyberprzemocy w oparciu o przygotowane wcześniej notatki. Następnie poszczególne grupy prezentują swoje prace na forum i przeprowadzona jest wspólna krótka dyskusja podsumowująca pierwsze spotkanie.

W przypadku młodzieży ze szkół ponadgimnazjalnych ta część może zostać zrealizowana w postaci udziału wszystkich uczniów w swobodnej dyskusji - burzy mózgów. Nauczyciel notuje refleksje uczniów tworząc wspólny kolaż. Na zakończenie spotkania każdy z uczniów odpowiada na pytanie - „Co zapamiętasz z obejrzanego filmu?”.

\subsection{SPOTKANIE 2.}

Zajęcia drugie w każdej z grup dotyczyć będą definiowania zjawiska cyberprzemocy i dróg jej rozprzestrzeniania. Celem jest zapoznanie uczniów z definicją zjawiska oraz zaprezentowanie dróg rozprzestrzeniania się zagrażającej ich rozwojowi cyberprzemocy. Drugie spotkanie w ramach programu profilaktycznego zaplanowane zostało na dwie godziny lekcyjne. Realizacja poszczególnych zadań w ramach programu będzie różnić się w zależności od tego, z jaką grupą wiekową pracuje nauczyciel.

Uczniowie klas szkoły podstawowej cyberprzemoc definiują poprzez wspólne wypisywanie skojarzeń z wyrazami takimi, jak „przemoc” $i$,internet”. Następnie pracując w parach, próbują stworzyć więcej określeń. Na koniec każda z par prezentuje efekty swojej pracy na forum grupy, a wszyscy uczniowie, biorąc udział w aktywnej dyskusji, podejmują próbę zdefiniowania zjawiska.

$\mathrm{W}$ drugiej części spotkania uczniowie zapoznają się z drogami rozprzestrzeniania cyberprzemocy. Dzieci w kilkuosobowych grupach tworzą plakaty zawierające wiadomości dotyczące cyberprzemocy $\mathrm{z}$ wykorzystaniem: komunikatora internetowego, poczty elektronicznej, wiadomości tekstowej, portalu społecznościowego blogów i stron internetowych. Następnie po zakończeniu pracy nauczyciel omawia z uczniami wykonane przez nich zadanie, wskazując na sposoby szerzenia się cyberprzemocy przy pomocy każdej z tych przestrzeni.

Młodzież ze szkół ponadgimnazjalnych definiuje zjawisko, dyskutując w grupie. Uczniowie wypisują wszystkie znane im informacje na temat cyberprzemocy, by potem wspólnie stworzyć definicję zjawiska. W drugiej części spotkania, dotyczącej dróg rozpowszechniania 
cyberprzemocy, nauczyciel dzieli uczniów na grupy. Każda z nich otrzymuje plakat z rozpoczętą historią, która zawiera w sobie hasła związane z cyberprzemocą. Młodzież dopisuje ciąg dalszy wydarzeń, po upływie czasu wyznaczonego przez nauczyciela przekazują plakat kolejnej grupie. Zadanie kończy się, gdy plakat ponownie znajdzie się w rękach pierwszej grupy. Na koniec zajęć nauczyciel omawia z uczniami pracę i zachęca do dyskusji.

\subsection{SPOTKANIE 3.}

Spotkanie trzecie w obu grupach wiekowych dotyczyć będzie form cyberprzemocy. Celem lekcji jest zaprezentowanie form zjawiska, a także ukazanie młodzieży zagrożeń związanych z każdą z nich. Spotkanie trwać będzie dwie godziny lekcyjne, a zadania realizowane w ramach tej części programu profilaktycznego będą odmiennie, w zależności od grupy wiekowej.

W grupie uczniów szkoły podstawowej zapoznają się oni z formami cyberprzemocy poprzez ćwiczenia grupowe. Nauczyciel dzieli dzieci na kilkuosobowe grupy. Każda z nich otrzymuje kartkę z konkretną formą cyberprzemocy: wojna na obelgi, prześladowanie i oczernianie, pozyskiwanie tajemnic, cyberostracyzm i cybernękanie oraz krótką jej charakterystyką. Zadaniem uczniów jest stworzenie drzewka decyzyjnego, zawierającego sytuacje z życia dziecka, w których mogą doświadczyć, bądź doświadczyli oni, którejś z form cyberprzemocy w realnym życiu. Po zakończeniu zadania nauczyciel omawia z uczniami wykonane prace, zachęcając do aktywnej dyskusji.

Młodzież ponadgimnazjalna formy cyberprzemocy poznaje w formie krótkiego wykładu nauczyciela. Następnie uczniowie, dzieląc się na kilkuosobowe grupy, mają wskazać negatywne konsekwencje każdej z form, odpowiadając na pytania: „Co jest nie tak w każdej z form?”,,Jak być powinno i dlaczego?". Po zakończeniu zadania nauczyciel omawia z uczniami jego wykonanie.

\subsection{SPOTKANIE 4.}

Czwarte spotkanie w obu grupach wiekowych dotyczyć będzie sprawców i ofiar cyberprzemocy. Trwać będzie dwie godziny lekcyjne, z możliwością dobrowolnego uczestnictwa rodziców w zajęciach. Celem przedostatniego spotkaniaw ramach programu profilaktykijestzaprezentowanie uczestnikom sylwetki sprawcy i ofiary - jej cech szczególnych czy charakterystycznych zachowań.

W grupie uczniów klas 5-8 zadanie to zostanie zrealizowane poprzez pracę w grupach i dyskusję. Uczniowie zostają podzieleni na grupy i wraz z rodzicami tworzą plakaty przedstawiające sylwetki ofiar i sprawców. Otrzymują od nauczyciela kartonik z określeniami charakteryzującymi ofiarę i sprawcę, takimi jak: „obniżone poczucie własnej wartości”, „smutek”, „strach”, „obawa w kontakcie z rówieśnikami”, ,atmosfera napięcia wokół siebie” „,nadruchliwość”, „wybuchowość”, „brak empatii”, „,chęć determinacji”. Dzieci mogą również dopisać swoje własne określenia, które kojarzą im się z danym zagadnieniem. Po wykonaniu plakatu następuje omówienie prac.

Uczniowie szkół ponadgimnazjalnych poznają sylwetkę sprawcy i ofiary podczas pracy 
w grupach. Uczestnicy spotkania są losowo przydzielani do grup. Jedna z nich słyszy od nauczyciela opowieść sytuacyjną, obrazującą postać sprawcy, a druga grupa opowieść dotyczącą ofiary. Stają się one charakterystyką sprawcy i ofiary cyberprzemocy. Następnie nauczyciel zadaje pytania dodatkowe każdej z grup. „Co czuje sprawca cyberprzemocy?”, „Jak myślisz, dlaczego ktoś stosuje cyberprzemoc?”, „Co czuje ofiara?”, „Jak można pomóc ofierze, będąc świadkiem cyberprzemocy?’. Każda z grup wspólnie pracuje nad odpowiedziami na pytania. Na zakończenie zajęć następuje prezentacja prac grupowych, ich omówienie oraz dyskusja.

\subsection{SPOTKANIE 5.}

Ostatnie zajęcia w obu grupach wiekowych dotyczyć będą konsekwencji cyberprzemocy, z wyszczególnieniem poszczególnych zaburzeń, jakie powstają na skutek jej długotrwałego doświadczenia. Celem ostatniego spotkania w ramach programu będzie także wskazanie dróg pomocy w przypadku doświadczania negatywnych sytuacji w sieci. Możliwy będzie dobrowolny udział rodziców. Spotkanie trwać będzie dwie godziny lekcyjne. Realizacja zadań w obrębie tematycznym spotkania będzie różnić się w zależności od grupy wiekowej, w której nauczyciel prowadzi zajęcia.

Uczniowie szkoły podstawowej poznają konsekwencje cyberprzemocy, takie jak: lęk, depresja, objawy somatyczne, myśli samobójcze i zaburzenia zachowania w formie prezentacji multimedialnej. Nauczyciel w trakcie omawiania poszczególnych zagadnień uwrażliwia zarówno młodzież jak i rodziców na objawy, mogące być sygnałem ostrzegawczym, że dzieje się coś niepokojącego. W drugiej części spotkania uczestnicy dowiedzą się, co zrobić, kiedy są świadkami cyberprzemocy, bądź też kiedy sami staną się jej ofiarami. Ponadto uzyskają niezbędne informacje dotyczące tego, w jaki sposób bezpiecznie korzystać z sieci. Ta część spotkania zrealizowana zostanie w formie dyskusji z aktywnym udziałem dzieci i rodziców.

Uczniom ze szkół ponadgimnazjalnych w ramach ostatniego spotkania prezentuje się kilkuminutowe filmy dotyczące konsekwencji długotrwałego doświadczania cyberprzemocy. Po każdej z projekcji następuje dyskusja z uczestnikami spotkania, dotycząca prezentowanych treści. W drugiej części ostatniego spotkania uczniowie i rodzice są losowo przydzielani do dwóch grup. Każda z nich, przy pomocy dostępnych materiałów i w oparciu o prezentowane filmy, tworzy plakat. Jeden - dotyczący konsekwencji cyberprzemocy pt. „Cyberprzemocy mówimy stanowcze nie”, drugi - prezentujący sposoby zapobiegania zjawisku pt. „Stop cyberprzemocy". Po zakończeniu zadania następuje podsumowanie cyklu spotkań w ramach realizacji programu.

\subsection{PODSUMOWANIE}

Najczęściej wykorzystywaną w ramach realizacji programu profilaktycznego formą aktywizacji uczniów jest praca $\mathrm{w}$ grupach oraz dyskusja. Wszystkie te działania w procesie kształcenia sprzyjają prawidłowemu realizowaniu zadań rozwojowych. Pomagają w rozwoju takich umiejętności, jak kształtowanie sumienia, moralności i wartości. Ułatwiają także osiągnięcie niezależności osobistej oraz rozwijają prawidłowe postawy wobec grupy (Ledzińska, 
Czerniawska 2011). Praca w grupie kształtuje u dzieci umiejętność współpracy, dzielenia zadań, kierowania pracą oraz współzawodnictwa. Uczy tolerancji i akceptacji wszystkich członków grupy. Dyskusja jest formą, w której uczeń może przedstawić swoje stanowisko, pogląd na dany temat, a także zapoznać się ze zdaniem innych. Uczy się krytycznego myślenia, argumentowania swojego stanowiska. Dyskusja daje nastolatkowi możliwość formułowania i przekazywania swoich myśli. Uczy go także tego, jak uważnie słuchać i dostrzegać opinii innych, co w znaczącym stopniu może wpływać na jego rozwój i kontakty z rówieśnikami. Wszelkie formy aktywizacji uczniów pomagają $\mathrm{w}$ radzeniu sobie $\mathrm{z}$ kryzysem rozwojowym okresu dorastania. Wpływają na ocenę własnych możliwości, a także sprawiają, że nastolatek stara się sprostać wymaganiom stawianym mu przez nauczyciela.

Profilaktyka zjawiska cyberprzemocy jest konieczna, gdyż zjawisko to niesie ze sobą szereg negatywnych skutków dla rozwoju dzieci i młodzieży. Wiedza na temat jej szkodliwości jest stosunkowo niewielka. Nowe technologie rozwijają się, a ryzyko zagrożeń z tym związanych wciąż rośnie i dotyka coraz to młodsze pokolenia. Warto więc zadbać o ochronę i wyposażyć nastolatków w wiedzę z zakresu szkodliwości i wpływu cyberprzemocy w ramach realizacji założeń programu profilaktycznego. Skuteczna pomoc wtym zakresie wymaga współpracy wielu jednostek zajmujących się ochroną zdrowia dzieci imłodzieży, a także nauczycieli i rodziców (Albański 2010).

\section{ZAKOŃCZENIE}

Globalność i rozległość sieci sprawia, że stanowi ona niezwykle trudny obszar do ochrony. Niełatwym zadaniem jest objęcie tej przestrzeni nadzorem, co w znaczącym stopniu utrudnia zapewnieniebezpieczeństwajegonajmłodszymużytkownikom(Guerreschi2006).Cyberprzemoc jest zjawiskiem o szerokiej skali, różnorodnych formach i drogach rozpowszechniania. Stanowi jeden z czynników zagrażających prawidłowemu rozwojowi. Oddziałuje na wiele aspektów w życiu nastolatka i wiąże się z wieloma konsekwencjami ważnymi dla zdrowia i rozwoju. Cyberprzemoc jest dla adolescentów źródłem stresu, zakłóca realizację zadań rozwojowych, wpływa na funkcjonowanie w środowisku oraz relacje jednostki z grupą rówieśniczą, często prowadząc do zaburzenia prawidłowego rozwoju. Istnieją badania potwierdzające związek cyberprzemocy ze wzrostem tendencji samobójczych w grupie nastolatków. Skala zjawiska cyberprzemocy jest duża i może wpływać na wiele aspektów życia młodzieży..

Profilaktyka zjawiska powinna być nastawiona na edukację młodzieży w zakresie bezpiecznego korzystania z internetu. Działania w ramach zajęć szkolnych powinny wspomóc zapobieganie zjawisku cyberprzemocy oraz stanowić formę ochrony młodych użytkowników internetu. W celu skutecznego zapobiegania zjawisku konieczna jest współpraca uczniów, rodziców i nauczycieli. Prewencja jest niezbędna, aby dbać o prawidłowy, zdrowy rozwój młodych użytkowników sieci. 


\section{BIBLIOGRAFIA}

Albański, Leszek. 2010. Wybrane zagadnienia z patologii społecznej. Jelenia Góra: Kolegium Karkonoskie. Państwowa Wyższa Szkoła Zawodowa.

Andrzejewska, Anna. 2014. Dzieci i młodzież w sieci zagrożeń realnych i wirtualnych: aspekty teoretyczne i empiryczne. Warszawa: Difin.

Becelewska, Daniela. 2006. Repetytorium z rozwoju człowieka. Jelenia Góra: Kolegium Karkonoskie. Państwowa Wyższa Szkoła Zawodowa.

Bee, Helen i Denise R. Boyd. 2008. Psychologia rozwoju człowieka. Poznań: Zyska i S-ka Wydawnictwo.

Brzezińska, Anna. 2000. Społeczna psychologia rozwoju. Wydanie 3. Warszawa: Wydawnictwo Naukowe Scholar.

Erikson, Erik H. 2004. Tożsamość a cykl życia. Poznań: Zysk i S-ka Wydawnictwo.

Farnicka, Marzanna, Hanna Liberska i Dorota Niewiedział. 2016. Psychologia agresji. Wybrane problemy. Warszawa: Wydawnictwo Naukowe PWN.

Guerreschi, Cesare. 2006. Nowe uzależnienia. Kraków: Wydawnictwo Salwator.

Harwas-Napierała, Barbara i Janusz Trempała. 2004.Psychologia rozwoju człowieka: Charakterystyka okresów życia człowieka. Warszawa: Wydawnictwo Naukowe PWN.

Kirwil, Lucyna. 2011. Polskie dzieci w Internecie: Zagrożenia i bezpieczeństwo-część

21-Częściowy raport z badań EU Kids Online przeprowadzonych wśród dzieci w wieku

9-16 lat i ich rodziców, http://eprints.lse.ac.uk/46445/ [Dostęp 10.02.2019]

Kołakowski, Artur. 2013. Zaburzenia zachowania u dzieci. Teoria i praktyka. Sopot: Gdańskie Wydawnictwo Psychologiczne.

Kowalski, Robin M., Sue Limber i Patricia W. Agatston. 2010. Cyberprzemoc wśród dzieci i młodzieży. Kraków: Wydawnictwo Uniwersytetu Jagiellońskiego.

Ledzińska, Maria i Ewa Czerniawska. 2011. Psychologia nauczania. Ujęcie poznawcze. Warszawa: Wydawnictwo Naukowe PWN.

Marasco, Thresa. 2012. Exploring depression: attachment, intimacy and personality traits. (Doctoral dissertation, Victoria University).

Mishna, Faye,Mona Khoury-Kassabri, Tahany Gadalla i Joanne Daciuk. 2012. Risk factors for involvement in cyber bullying: Victims, bullies and bully-victims. "Children and Youth Services Review" 34(1): 63-70. DOI: https://doi.org/10.1016/j.childyouth.2011.08.032

Monks, Claire P. i Iain Coyne. 2012. Przemoc i mobbing $w$ szkole, $w$ domu, w miejscu pracy. Warszawa: Wydawnictwo Naukowe PWN.

Ponczek, Danuta i Iwona Olszowy. 2012. Styl życia młodzieży i jego wpływ na zdrowie. „Problemy Higieny i Epidemiologii” 93(2): 260-268.

Przetacznik-Gierowska, Maria iMaria Tyszkowa. 1996. Psychologia rozwoju człowieka. Zagadnienia ogólne. Warszawa: Wydawnictwo Naukowe PWN.

Pużyński, Stanisław i Jacek Wciórka. 2000. Klasyfikacja zaburzeń psychicznych i zaburzeń zachowania w ICD-10: badawcze kryteria diagnostyczne. Warszawa: Uniwersyteckie Wydawnictwo Medyczne Vesalius.

Sęk, Helena (red.). 2008. Psychologia kliniczna. Warszawa: Wydawnictwo Naukowe PWN. 
Sourander, Andre, Anat B. Klomek, Maria Ikonen et al. 2010. Psychosocial Risk Factors Associated with Cyberbullying AmongAdolescents: A Population-BasedStudy. „Arch Gen Psychiatry" 67(7): 720-728. DOI: 10.1001/archgenpsychiatry.2010.79

Szeligiewicz-Urban, Danuta (red.).2016. Uczeń bezpieczny w cyberprzestrzeni. Sosnowiec: Oficyna Wydawnicza „Humanitas”.

Wojciszke, Bogdan. 2006. Człowiek wśród ludzi: zarys psychologii społecznej. Warszawa: Wydawnictwo Naukowe Scholar

Zimbardo, Philip G. i Richard J. Gerrig. 2008. Psychologia i życie. Warszawa: Wydawnictwo Naukowe PWN.

Use of the Internet as a source of danger to the health and development of children and young people

ABSTRACT: Cyber-bullying is a type of aggression that threatens the health and development of children and young people. The consequences of experiencing it are behavioural disorders, anxiety, somatic symptoms and suicide among teenagers. The first part of the article defines the phenomenon of cyber-bullying, its forms and ways of dissemination. The disorders threatening the health and development of adolescents as well as the research in the field of cyber-violence are presented. The second part is a presentation of theoretical assumptions that explain the harmfulness of the impact of cyber-bullying on the development of teenagers, while the third part is a proposal for a school prevention programme protecting young network users.

KEYWORDS: cyberbullying, health, children, teenager 